\title{
PENCEGAHAN TERJADINYA LOW BACK PAIN (LBP) TERKAIT DUDUK YANG BENAR PADA MAHASISWA STIKES SUAKA INSAN BANJARMASIN
}

\author{
Dadan Prayogo ${ }^{1 *}$, Sutikno $^{2}$ \\ ${ }^{1,2}$ Program Studi Sarjana Fisioterapi, Stikes Suaka Insan Banjarmasin \\ *Email: dadanprayogo@gmail.com
}

\begin{abstract}
ABSTRAK
Low back pain (LBP) adalah suatu keadaan tidak nyaman atau rasa nyeri yang akut pada daerah ruas lumbalis kelima dan sakralis (L5-S1). Penyuluhan ini bertujuan untuk pencegahan terjadinya LBP terkait duduk yang benar pada mahasiswa Stikes Suaka Insan Banjarmasin. Metode yang digunakan yaitu dengan cara pengisisan angket sebelum dan sesudah pemaparan materi terkait cara duduk yang benar dengan 37 responden. Hasil penyuluhan ini menunjukkan bahwa sebelum pemaparan materi masih banyak terdapat responden yang tidak mengetahui bagaimana cara duduk yang benar dan setelah mendapatkan pemaparan materi didapatkan hasil dari setiap pertanyaan satu sampai dengan pertanyaan nomor empat didapatkan nilai 37 (100\%) dan pertanyaan nomor lima didapatkan 36 (97,29\%). Kesimpulan dari penyuluhan ini pemaparan materi di terima dengan baik oleh responden terkait dengan cara duduk yang benar dilihat dari hasil angket sebelum dan sesudah pemaparan materi.
\end{abstract}

Kata Kunci: Low Back Pain, Posisi Duduk yang Benar, Upaya Pencegahan.

\section{A. PENDAHULUAN}

Low back pain (LBP) adalah suatu keadaan tidak nyaman atau rasa nyeri yang akut pada daerah ruas lumbalis kelima dan sakralis (L5-S1). Nyeri yang dirasakan pada punggung bawah, biasanya disertai dengan penjalaran dari arah kaki dan tungkai (Mahendra, 2018). LBP adalah salah satu masalah muskuloskeletal paling umum yang mempengaruhi kualitas hidup, pada lansia, dengan $80 \%$ populasi umum telah dilaporkan mengalami LBP setidaknya sekali dalam seumur hidup mereka (Park, et al. 2019). Menurut Kim, et al. (2017)
LBP adalah masalah muskuloskeletal yang paling umum yang dapat mempengaruhi gaya hidup seseorang.

Prevalensi di Amerika Serikat, LBP berada pada peringkat ke 5 dalam daftar penyebab kunjungan ke dokter yakni sekitar 12 juta kunjungan per tahun. LBP pada pekerja di negara industri mencapai $70 \%$, demikian pula halnya dengan prevalensi pada usia sekolah (Burton, et al. 2006). Angka pasti kejadian LBP di Indonesia tidak diketahui, namun diperkirakan, angka prevalensi LBP bervariasi antara 7,6\% sampai 37\%. Dari data yang 
dikumpulkan di poliklinik saraf RSUP

Dr. Sardjito tahun 2000, pasien yang datang tiap bulannya adalah berkisar antara 1.500 pasien sampai dengan 2.000 pasien, yang terbanyak adalah pasien nyeri pinggang, (Winata, 2014).

Penelitian kelompok Perhimpunan Dokter Spesialis Saraf Indonesia (PERDOSSI) Mei 2002 menunjukkan jumlah penderita LBP yaitu $18,37 \%$ dari seluruh pasien nyeri. Studi populasi di daerah pantai utara Jawa ditemukan insidensi $8,2 \%$ pada pria dan $13,6 \%$ pada wanita. Di Rumah Sakit Jakarta, Yogyakarta dan Semarang insidensinya sekitar 5,4$5,8 \%$, frekuensi terbanyak pada usia 45-65 tahun (Harsono, 2009). Prevalensi LBP yang terjadi di lingkungan kerja anestesiologi dan terapi intensif R.S. Dr. Hasan Sadikin Bandung tahun 2014 sebesar 35,7\% (Patrianingrum, et al. 2015).

Gangguan yang sering terjadi pada LBP yaitu nyeri pada daerah punggung bawah, spasme pada otototot punggung bawah, sehingga menyebabkan terjadinya ketidakseimbangan antara otot abdominal dan paravertebra yang dapat menimbulkan keterbatasan saat bergerak. Hal ini akan mengakibatkan penurunan mobilitas lumbal yang disebabkan karena adanya nyeri, spasme, ketidak seimbangan otot abdominal dan paravertebra, sehingga aktivitas fungsional terganggu. Dampak lain dari LBP salah satunya adalah nyeri, yang berpengaruh terhadap penurunan aktivitas fisik, penurunan mobilitas dapat menyebabkan perubahan signifikan dalam status kesehatan dan kualitas hidup dalam jangka panjang (Vanti, et al. 2019). Hal ini sesuai dengan pernyataan Kusuma, et al. (2014) bahwa LBP merupakan gejala utama yang dilaporkan kepada praktisi kesehatan berkaitan dengan menurunnya produktivitas kerja.

LBP merupakan salah satu penyebab utama terbatasnya aktivitas dan ketidakhadiran kerja dan dikaitkan dengan beban ekonomi yang sangat besar. Meskipun riwayat alami dari kondisi ini sembuh sendiri 90\% biasanya dalam dua bulan dan dapat kembali ke aktivitas normal, namun terdapat risiko tinggi bahwa $10 \%$ sisanya mengalami nyeri kronis dan kecacatan. Diantara faktor-faktor yang dapat berkontribusi pada kondisi nyeri muskuloskeletal kronis, penurunan aktivitas fisik adalah salah satu yang paling relevan. Selain itu, berkurangnya mobilitas dapat menyebabkan perubahan signifikan pada status kesehatan dan kualitas 
hidup dalam jangka panjang (Vanti, et al. 2019).

Faktor risiko LBP yang dapat menyebabkan terjadinya keluhan LBP yaitu: Faktor internal terdiri dari usia, jenis kelamin, kebiasaan merokok, IMT, kebiasaan olahraga, (Tanderi, 2017). Faktor eksternal terdiri dari beban, kerja, masa kerja, beban angkat, sikap kerja yang terdiri dari duduk, berdiri dan membungkuk (Tarwaka, et al. 2016). Faktor lingkungan terdiri dari temperature ekstrim dan getaran (Haikal, 2018). Posisi duduk merupakan kegiatan yang terlihat begitu mudah untuk dilakukan, sehingga banyak yang mengabaikan bagaimana posisi duduk yang benar. Tetapi perlu diketahui bahwa posisi duduk yang tidak benar dapat memberikan dampak buruk terhadap kesehatan tubuh. Sehingga perlunya upaya pencegahan serta edukasi dalam meningkatkan pengetahuan mahasiswa STIKES Suaka Insan Banjarmasin terhadap posisi duduk yang benar, dimana mahasiswa merupakan bagian dari masyarakat dan terlebih sebagai mahasiswa yang bergerak dalam bidang kesehatan.

\section{B. METODE}

Kegiatan penyuluhan diawali dengan pengisian angket bertujuan untuk mengetahui tingkat pengetahuan responden/mahasiswa terkait duduk yang benar untuk kesehatan pinggang. Setelah pengisisan angket selesai selanjutnya pemaparan materi terkait dengan cara duduk yang benar, serta mendemonstrasikan postur yang baik dan ergonomis, baik dalam posisi duduk maupun kegiatan lain yang berisiko menyebabkan nyeri punggung misalnya mengangkat benda berat. Setelah pemaparan materi selesai seluruh responden dipersilakan untuk bertanya untuk membuat suasana diskusi interaktif, dilakukan juga pengisisan angket sesudah pamaparan materi untuk mengetahui tingkat pengetahuan responden/mahasiswa setelah pemaparan materi terkait dengan duduk yang benar untuk kesehatan pinggang. Pengabdian masyarakat ini dilakukan di aula Stikes Suaka Insan Banjarmasin pada hari minggu 21 November 2021, berlangsung dari pukul 09.00-11.30 Wita. Penelitian ini bertujuan untuk pencegahan terjadinya LBP terkait duduk yang benar pada mahasiswa Stikes Suaka Insan Banjarmasin.

Target populasi dalam penelitian ini adalah mahasiswa Stikes Suaka Insan Banjarmasin. Sampel dalam penelitian ini adalah mahasiswa sarjana keperawatan smester I dan mahasiswa 
sarjana Fisioterapi semester I dan III dengan jumlah 37 mahasiswa.

\section{HASIL DAN PEMBAHASAN}

Selama masa pandemi COVID19, terdapat protokol kesehatan yang harus dipatuhi, antara lain mencuci tangan atau menggunakan hand sanitizer, menggunakan masker, menjaga jarak, serta membatasi responden/mahasiswa dalam satu ruangan.

Tabel 1.1 Angket Sebelum Pemaparan Materi

\begin{tabular}{|c|c|c|c|c|}
\hline No & Pextanyaan & $\mathbf{n}$ & $\begin{array}{l}\text { Setuiu } \\
\text { n }(\%)\end{array}$ & $\begin{array}{l}\text { Tidak } \\
\text { Setuiu } \\
\text { n }(\%)\end{array}$ \\
\hline 1 & $\begin{array}{l}\text { Duduk dengan dada sondong } \\
\text { kedepan merupakan posisi duduk } \\
\text { yang benar. }\end{array}$ & 37 & $\begin{array}{c}32 \\
(86,48)\end{array}$ & $\begin{array}{c}5 \\
(13,51)\end{array}$ \\
\hline 2 & $\begin{array}{l}\text { Mendekatkan meja dan kursi } \\
\text { membuat otot punggung meniadi } \\
\text { lebih rileks. }\end{array}$ & 37 & $\begin{array}{c}20 \\
(54,05)\end{array}$ & $\begin{array}{c}17 \\
(45,94)\end{array}$ \\
\hline 3 & $\begin{array}{l}\text { Duduk tegak dengan punggung } \\
\text { lurus dan bahu ke belakang. } \\
\text { Bokong menyentuh bagian } \\
\text { belakang bursi merupakan sara } \\
\text { duduk yang benar }\end{array}$ & 37 & $\begin{array}{c}11 \\
(29,72)\end{array}$ & $\begin{array}{c}26 \\
(70,27)\end{array}$ \\
\hline 4 & $\begin{array}{l}\text { Faktor risike teriadinya LBP } \\
\text { salah satunya adalah posisi } \\
\text { duduk. }\end{array}$ & 37 & $\begin{array}{c}22 \\
(59,45)\end{array}$ & $\begin{array}{c}15 \\
(40,54)\end{array}$ \\
\hline 5 & $\begin{array}{l}\text { Geiala dari LBP salah satunya } \\
\text { adalah nveri dan spasme }\end{array}$ & 37 & $\begin{array}{c}30 \\
(81,08)\end{array}$ & $\begin{array}{c}7 \\
(18,91)\end{array}$ \\
\hline
\end{tabular}

Berdasarkan Tabel 1.1 diatas sebelum pemaparan materi masih banyak terdapat responden yang tidak mengetahui bagaimana cara duduk yang benar terlihat dari pertanyaan nomor satu terdapat 5 (13,51\%). Pertanyaan nomor dua terdapat 17 $(45,94 \%)$, pertanyaan nomor tiga terdapat $26(70,27 \%)$, pertanyaan nomor empat dan nomor lima yaitu 15 $(40,54 \%)$ dan $7(18,91 \%)$.
Postur saat duduk dipengaruhi oleh sudut sandaran punggung, sudut dudukan kursi dengan keempukan busa, dan ada atau tidaknya sanggahan tangan. Sandaran punggung yang memiliki sudut $110^{\circ}-130^{\circ}$ adalah tumpuan yang paling ideal karena menghasilkan tekanan paling rendah bagi diskus intervertebralis dengan kerja otot yang paling ringan. Dudukan kursi yang memiliki sudut $5^{\circ}$ dan 
sanggahan tangan juga dapat

menurunkan tekanan diskus intervertebralis dan kerja otot saat duduk (Widiasih, 2015). Duduk menyebabkan pelvis berotasi ke arah belakang. Rotasi dari pelvis dapat mengubah derajat sudut lumbar lordosis, dan menambah derajat persendian pada panggul dan derajat persendian pada lutut. Hal ini membuat usaha yang dilakukan otot menjadi lebih berat, sehingga kerja otot meningkat dan menekan diskus vertebralis (Widiasih, 2015). Semakin sering mahasiswa merubah posisi pada saat duduk, maka tingkatan nyeri yang dirasakan akan semakin ringan, karena perubahan posisi dapat merelaksasikan otot-otot punggung yang mengalami tekanan akibat duduk dalam jangka waktu lama (Wulandari, 2010).

Tabel 1.2 Angket Sesudah Pemaparan Materi

\begin{tabular}{|c|c|c|c|c|}
\hline No & Pertanyaan & $\mathbf{n}$ & $\begin{array}{l}\text { Setuiu. } \\
\text { n (\%) }\end{array}$ & $\begin{array}{l}\text { Tidak } \\
\text { Setuiu } \\
\text { n (\%) }\end{array}$ \\
\hline 1 & $\begin{array}{l}\text { Duduk dengan dada sendeng } \\
\text { kedepan merupakan pesisi } \\
\text { duduk yang benar. }\end{array}$ & 37 & $\begin{array}{c}37 \\
(100)\end{array}$ & - \\
\hline 2 & $\begin{array}{l}\text { Mendekatkan meia dan bursi } \\
\text { membuat stot punggung } \\
\text { meniadilebih rileks }\end{array}$ & 37 & $\begin{array}{c}37 \\
(100)\end{array}$ & - \\
\hline 3 & $\begin{array}{l}\text { Duduk tegak dengan punggung } \\
\text { lurus dan bahu ke belakang. } \\
\text { Bokeng menyentuh bagian } \\
\text { belakang kursi merupakan sara } \\
\text { duduk yang benar. }\end{array}$ & 37 & $\begin{array}{c}37 \\
(100)\end{array}$ & - \\
\hline 4 & $\begin{array}{l}\text { Faktor risike teriadinxa LBP } \\
\text { salah satunya adalah pesisi } \\
\text { duduk. }\end{array}$ & 37 & $\begin{array}{c}37 \\
(100)\end{array}$ & - \\
\hline 5 & $\begin{array}{l}\text { Geiala dari LBP salah satunya } \\
\text { adalah nyeri dan spasme }\end{array}$ & 37 & $\begin{array}{c}36 \\
(97,29)\end{array}$ & $\begin{array}{c}1 \\
(2,70)\end{array}$ \\
\hline
\end{tabular}

Berdasarkan Tabel 1.2 setelah mendapatkan pemaparan materi didapatkan hasil dari setiap pertanyaan satu sampai dengan pertanyaan nomor empat didapatkan nilai 37 (100\%) dan pertanyaan nomor lima didapatkan 36 $(97,29 \%)$. sehingga dapat disimpulkan pemaparan materi di terima dengan baik oleh responden terkait dengan cara duduk yang benar. 
Lama duduk juga dapat menimbulkan terjadinya spasme otot atau ketegangan pada daerah pantat. Pekerja perlu diberikan istirahat aktif untuk dapat menghindari pekerjaan yang monoton dalam jangka waktu lama, dan relaksasi untuk mengendorkan ketegangan saraf dan otot akibat kerja. Sehingga kejenuhan kerja dapat dikurangi, memulihkan kesegaran mental, dan akhirnya dapat meningkatkan produktivitas kerja (Rahmat et all, 2019). Nyeri punggung tersebut dapat terjadi pada berbagai situasi kerja, tetapi risikonya lebih besar apabila duduk lama dalam posisi statis karena akan menyebabkan kontraksi otot yang terus menerus serta penyempitan pembuluh darah. Pada penyempitan pembuluh darah aliran darah terhambat dan terjadi iskemia, jaringan kekurangan oksigen dan nutrisi, sedangkan kontraksi otot yang lama akan menyebabkan penumpukan asam laktat, kedua hal tersebut menyebabkan nyeri (Rahmat et all, 2019). Lama duduk dapat berdiri sendiri sebagai faktor resiko yang signifikan untuk LBP, kecuali jika dikombinasikan dengan sikap duduk yang salah dan getaran pada tubuh maka mungkin akan meningkatkan resiko berkembangnya LBP (Rahmat et all, 2019). Terlalu lama duduk dan dengan posisi yang kurang tepat membuat orang capek dan kurang efisien bekerja. Posisi lordosis yaitu membungkuk dengan beban pada tulang belakang yang terlalu banyak merupakan gangguan otot utamanya otot perut dan otot punggung yang menjadi sebab nyeri punggung bawah (Rahmat et all, 2019).

\section{KESIMPULAN}

Mayoritas usia produktif pernah mengalami nyeri punggung bawah selama hidupnya, memahami bahwa postur dan posisi duduk dapat menyebabkan nyeri punggung, namun belum semuanya mengetahui ciri postur dan posisi duduk yang baik untuk pencegahan nyeri punggung bawah. Penyuluhan ini dapat menjadi suatu alternatif yang efektif bagi mahasiswa dalam tindakan preventif nyeri punggung bawah dengan cara meningkatkan pengetahuan mahasiswa dengan suasana yang interaktif. Kesimpulan dari penyuluhan ini pemaparan materi di terima dengan baik oleh responden terkait dengan cara duduk yang benar dilihat dari hasil angket sebelum dan sesudah pemaparan materi. 


\section{DAFTAR PUSTAKA}

Burton, A., Balague, F., Cardon, G., Eriksen, H., Henrotin, Y., Lahad, A., Leclerc, A., Muller, G. and van der Beek, A., 2006. European guidelines for prevention in low back pain. European Spine Journal, 15: 136-168. Haikal, M., 2018. J Agromedicine. Volume 5, Nomor1, Juni 2018. 529 Tinjauan Pustaka Risiko Low Back Pain (LBP) pada Pekerja dengan PaparanWhole Body Vibration (WBV). Fakultas Kedokteran, Universitas Lampung, Volume 5: 1.

Harsono, 2009. Kapita Selekta Neurologi. Yogyakarta: Gadjah Mada University Press, 2.

Kim, H., Min, T. J., Kang, S. H., Kim, D. K., Seo, K. M. and Lee, S. Y., 2017. Association between walking and low back pain in the Korean population: A cross-sectional study. Annals of Rehabilitation Medicine, 41: 786-792.

Kusuma, I. F., Hasan, M. and Ragil, I. H., 2014. Pengaruh Posisi Kerja Terhadap Kejadian Low Back Pain pada Pekerja di Kampung Sepatu, Kelurahan Miji, Kecamatan Prajurit Kulon, Kota Mojokerto. Fakultas Kedokteran Universitas Jember: 59-66.

Mahendra, A., 2018. Low Back Pain. respirasi UNIMUS.

Park, S. M., Kim, G. U., Kim, H. J., Kim, H., Chang, B. S., Lee, C. K. and Yeom,
J. S., 2019. Walking more than 90minutes/week was associated with a lower risk of self-reported low back pain in persons over 50years of age: a cross-sectional study using the Korean National Health and Nutrition Examination Surveys. Spine Journal, 19: 846-852.

Patrianingrum, M., Oktaliansah, E. and Surahman, E., 2015. Prevalensi dan Faktor Risiko Nyeri Punggung Bawah di Lingkungan Kerja Anestesiologi Rumah Sakit Dr. Hasan Sadikin Bandung. Jurnal Anestesi Perioperatif, 3: 47-56.

Rachmat, N., Utomo, P. C., Sambada, E. R., \& Andyarini, E. N. 2019, 'Hubungan Lama Duduk dan Sikap Duduk Terhadap Keluhan Nyeri Punggung Bawah Pada Penjahit Rumahan Di Kecamatan Tasikmadu', Journal of Health Science and Prevention, 3(2), 79-85

http://jurnalfpk.uinsby.ac.id/index.php /jhsp/article/view/204

Tanderi, E. A., 2017. Low Back Pain bab II Tinjauan Pustaka. eprints UNDIP.

Tarwaka., Bakri, S. H. A. and Sudiajeng, L., 2016. Ergonomi untuk Keselamatan, Kesehatan Kerja dan Produktivitas.

Vanti, C., Andreatta, S., Borghi, S., Guccione, A. A., Pillastrini, P. and Bertozzi, L., 2019. The effectiveness of 
walking versus exercise on pain and function in chronic low back pain: a systematic review and meta-analysis of randomized trials. Disability and Rehabilitation, 41: 622-632.

Widiasih, G. 2015, 'Hubungan Posisi Belajar dan Lama Duduk dengan Kejadian Nyeri Punggung Bawah Mahasiswa PSPD FKIK UIN Jakarta', Available at: http://repository.uinjkt.ac.id/dspace/bi tstream/123456789/29488/1/ghina\%2 Owidiasih-fkik.pdf
Winata, S. D., 2014. Diagnosis dan Penatalaksanaan Nyeri Punggung Bawah dari Sudut Pandang Okupasi. Journal Kedokteran Meditek, 20: 2027.

Wulandari, I. D. 2010, 'Hubungan lama dan sikap duduk perkuliahan terhadap keluhan nyeri punggung bawah miogenik pada mahasiswa di universitas muhammadiyah surakarta', Pena Jurnal Ilmu Pengetahuan dan Teknologi, Available at: https://jurnal.unikal.ac.id/index.php/p ena/article/viewFile/149/149 